INTERMARUM: history, policy, culture. - Issue 9.

UDC 94(477.83):335.316«1944-1953»

DOI 10.35433/history.112023

\author{
Starodubets Galyna, \\ PhD hab. (History), Professor, \\ Head of the Department of the World History \\ Zhytomyr Ivan Franko State University \\ starodubec@gmail.com \\ ResearcherID M-9514-2015 \\ https://orcid.org/0000-0003-2005-771X
}

\title{
ANTHROPOLOGY OF MEMORY OF RURAL WOMEN OF ZHYTOMYR REGION ABOUT POST-WAR EVERYDAY LIFE
}

\begin{abstract}
The purpose of the study. The peculiarities of everyday life in the Ukrainian village during the late Stalinism in the framework of women's survival experience during the first postwar decade are highlighted in the article. The research is based on the memories of peasant women of Zhytomyr region, whose childhood took place in the 1940s. Methodological basis of the study is historical-anthropological approach, with one of its manifestations being the history of everyday life. Scientific novelty. The research of rural everyday life of peasants in Zhytomyr region from the standpoint of gender approach is accomplished for the first time. The survival strategies of rural women in the postwar period are emphasized. The following components of rural everyday life are analysed: work in a collective farm, ways to meet the material and household needs of the family, the behaviour of peasants in the famine circumstances in 1946-1947. Conclusions. Women's survival strategies in the post-war everyday life were distinguished by extreme nature and ability to adapt to circumstances. During that period, the epicenter of rural life was not a private family but a collective farm as an important economic and social institution. The famine, hard work of the collective farm and the poverty of post-war everyday life still remain a painful stigma in the social memory of rural women.
\end{abstract}

Key terms: rural women, everyday life, famine, women, collective farm, Soviet Power, Zhytomyr region

The statement of the problem. For a long time, the history of the Second World War was learnt in a framework of the study of its political, economic and military aspects on a one hand and glorification of the most significant figures of the Soviet party establishment on the other. The 
ІНТЕРМАРУМ: історія, політика, культура. - Вип. 9.

average person, who was not considered as a full-fledged subject of historical processes, remained outside the scope of scientific interests. In recent decades, there has been a substantive expansion of individual objects of study in historical science on the basis of new methodological approaches, in particular, historical-anthropological. One of its manifestations is the history of everyday life, «(everyday life history, Alltagsgeschichte, histoire de la vie quotidienne) - a new branch of historical knowledge, the subject of which is the sphere of human everyday life in multiple historical-cultural, political-eventful, ethnic and religious contexts» (Pushkareva, Liubychankovskyi, 2014, p.7). The verage person with his/her everyday problems, way of life, survival strategies in times of crisis of revolutionary, military, political transformations is the key in the analysis of everyday life. Methodological principles of studying the problems of everyday life of society are still not established, since the history of everyday life is interpreted in two ways - as a separate area of research, as well as one of the methodological techniques for a deeper study of individual historical events or phenomena. We completely agree with the researcher's opinion that «the inductive way - the way of knowing the whole (reconstruction of the life of the whole society) through the knowledge of the individual (reconstruction of life and everyday life of individuals) - looks quite a successful direction of reconstruction of past centuries») (Asheshkevych, 2017).

The analysis of recent researches and publications. In modern Ukrainian historiography, a considerable layer of scientific works on the problems of the Second World War and the postwar decade has been formed; it is based on the methodological principles of the history of everyday life. In her works Tereshchenko T. (Tereshchenko, 2016) analyzes the influence of various factors on the situation of the peasantry in the period of late Stalinism. Survival strategies implemented by the population of the northern region of Ukraine in the conditions of insufficient and uneven consumer provision during the first year after the liberation of the territory from the German occupiers are considered in the article by O. Baklazhko (Baklazhko, 2013). The stressful nature of the famine of 1946-1947 on the villagers is discussed in the work of V. Michuda (Michuda, 2017). Material and living conditions of the population in the years of postwar reconstruction are studied by O. Isaykina (Isaykina), L. Kovpak (Kovpak, 2015), S. Savytska 
INTERMARUM: history, policy, culture. - Issue 9.

(Savytska, 2015) and others. Some aspects of everyday life of rural women in 1945-1953 are considered in a number of works by G. Starodubets (Starodubets, 2019) and I. Sushyk (Starodubets, Sushyk, 2021) in the context of their analysis of the gender policy of the Stalinist regime. However, the problem of everyday strategies for the survival of rural women in the postwar decade in the regional context of Zhytomyr Polissya and Podillya still remains out of researchers'.

The purpose of our article is to highlight the peculiarities of everyday life in the Ukrainian village during the late Stalinism in the framework of women's experience of survival during the first postwar decade. The study is based on the memories of rural women of Zhytomyr region, whose childhood took place in the 1940s. Field research was carried out during 2017-2021 in the framework of the project «Gender Studies» of the Laboratory of the Study of the Soviet past during the Stalin era of Zhytomyr Ivan Franko State University.

The statement of basic material.The Nazi occupation of Zhytomyr region lasted for about 2.5 years. Its consequences, among others, were the destruction of the socio-economic system formed in the region during the 1930s and early 1940s. The agricultural sector suffered particularly significant losses. According to official data, «the Slovechansky district was almost completely destroyed, the Olevsk district was destroyed more than by a half, the Luhinsk and Ovruch districts - more than 30 villages were burned to the ground; almost all collective farmers from the Chernyakhiv district and a large number of villages in the Zhytomyr district were evicted» (CSAPOU, f.1, op.70, spr.197, ark. 74). As the region we study is mainly agricultural, the standard of living of local residents was extremely low compared to other areas where industry accounted for a larger share of the general sector of the economy. Exhausted by the war, the peasants were in an extremely miserable situation, which in many cases was worsened by the loss of their own homes, burned by the occupiers as a means of collective responsibility for the sabotage of partisan rebel units operating in Polissya forests.

The official policy of the Bolshevik-Soviet state was totalitarian in nature and was aimed primarily at ensuring its military power. Addressing the social needs of the population has never been a priority for the communist government, especially during the aggravation of the international situation in the context of the Cold War. Traditionally, the 
ІНТЕРМАРУМ: історія, політика, культура. - Вип. 9.

most disenfranchised social group in the USSR was the peasantry, whom «the state's policy on the village pushed to the lowest level of society» (Yankovska, 2010, p.177). Deprived of property rights, collective farmers were considered by the Stalinist regime as free labor in agriculture and as an inexhaustible source of cheap labor for heavy and mining industries. Burdened with an unbearable taxation, the peasants were forced to give the main share of income from meager pieces of land to the state. The work in the collective farm was in fact slavish because it had not been paid for a long time.

The change in the demographic structure of society is a consequence of any social cataclysm. The Ukrainian village in the postwar period had a female face. It was the woman who carried the burden of the post-war life on her shoulders: raising children, working at home and in the collective farm, looking for ways and means of material and financial support for the family, and during the famine of 1946-1947 - food to support the family. The survival strategies of rural women were fundamentally different from those of urban women. Therefore, their memories are filled with an emotional palette dominated by dark colors.

During the liberation of Zhytomyr region from the German occupiers, the difficult socio-economic situation of the Polissya village was exacerbated by the pressure of mobilization campaigns conducted by the authorities to replenish the army with human resources. As a result, rural families lost their breadwinners as almost the entire adult male population was mobilized to the front. «Well, as the war was extended, in 1943», recalls Galyna Afanasieva, «my father was taken away and my brother went to war. They both left, we, the smaller, were left. Ivan was the oldest among us» (Afanasieva, 1933r.n.).

All respondents recall the difficult working conditions in which women had to work with deep pain. «Lord, we all suffered in different ways. There was no one to work. These women are poor, harnessed to those cows; and they plowed and loosened with cows. And tried to cultivate the land at least for themselves. They went to the field, they were chased. She had no rights to go to bed and sleep at night. It's all night you have to tie up the sheaves and the hoe is with her. Tied up and go to hoe the beetroot. Everything was done manually. It was very difficult for them» (Afanasieva, 1933r.n.). «Women were in the fields, weeding beetroots, mowing wheat with sickles, tying up the sheaves, loading them on trucks and driving them to the machine to thresh. The 
INTERMARUM: history, policy, culture. - Issue 9.

children all worked in the collective farm as much as they could. I went to the sixth grade, I already helped my mother to dig the beetroots», recalls Soroka Maria (Soroka, 1940 r.n.).

Despite the critically difficult social situation of the Ukrainian peasantry, the Stalinist regime severely suppressed any attempts to introduce an alternative to collective farms form of management. In fact, there were almost no such attempts, but the communist authorities tried to control public mood by preventing the spread of «seditious» thoughts. Local branches of the NKVD closely monitored the political mood of the peasants and recorded any manifestations of free thought expressed by the peasants at collective farm meetings, in private conversations, etc. We have evidence that «in February 1945, at a meeting of collective farmers dedicated to the work of collective farms, Poteychuk Fedir stated: «It is not necessary to work in a collective farm, since a collective farmer does not receive any income. Everything they earn goes to the state and leaders, and regular collective farmers are not given anything. In the collective farm, everything is built on deception» (SAZhR, f.p-76, op.2, spr.227, arc.14). «In March the same year in the village. Motovylivka of Liubar district, a resident of the village Kondrashyna Paraska said: «How long will we go to work to the collective farm, where we are being deceived. We don't need a collective farm» (SAZhR, f.p-76, op.2, spr.227, arc.15). Such statements were not unnoticed for their speakers. The Bolshevik government could not allow the spread of ideas that could hypothetically undermine the authority of the Communist Party and seed doubt in correctness of its state policy. As a rule, such people were declared enemies of the people, criminals and subjected to repression in the form of arrest and prosecution.

In their memoirs, the respondents also mention repressions against fellow villagers, such as T. Pantus: «Zhora Pyrig took off the slogan at the store «Long life to Comrade Stalin» or something like that. They took him, he was still a young boy, and he was in prison» (Pantus, 1925 r.n.). However, they are not willing to express their attitude to such events. Some justify the policy of the Stalinist regime, «because then it was difficult, there was destruction. And Stalin endured such a war. Without Stalin, we would have been defeated a long time ago» (Pylypchuk, 1935 r.n); «if he was not so cruel, the war would not end in our victory. He even sacrificed his son in the name of victory» (Lompas, 1939 r. n.). 
ІНТЕРМАРУМ: історія, політика, культура. - Вип. 9.

Poor post-war everyday life and absolute material and financial dependence on the will of the collective farm leadership on the one hand, and total pressure on the Bolshevik ideological machine, on the other hand, contributed to the formation of a lasting sense of fear as a kind of defensive reaction to criticism of the Stalinist regime. «Because of a word, if he said something bad, he would be the enemy. Therefore, no one said anything. People believed that everything will be fine. If they had any anger at Stalin, or suspected him of any arrangements with Hitler - there was no such thing at all. They did not know or hear about the party. The Communist Party, we believed that it was the head of our state. All conversations were forbidden», says M. Vasyliuk (Vasyliuk, 1931 r.n.). Most of the peasants were not ready to actively oppose the measures imposed on the peasants by the Bolshevik-Soviet authorities. Even if such measures were clearly repressive. People who survived the horrors of war and German occupation eagerly awaited peace and, under the influence of Stalinist propaganda, sincerely believed in the correctness of the policies of the Communist Party and the government. The difficulties of the postwar period were perceived as temporary, caused by the need to rebuild the national economy of the Soviet country.

The majority of the peasantry perceived the restoration of the collective farm system immediately after liberation from German occupation as extremely negative, since the memories of the Holodomor of 1933, repressions and expropriation by local activists against peasants who resisted collectivization were still alive. However, it was not possible to avoid collective farm slavery, because «those who did not go to the collective farm were taxed or their land was plowed» (Halitska, 1936 r.n.). «Those who did not want to go, to their house they will come, will cut the land, sow it with lupine from collective farm. If you have hay, they will come to mow and take the cow to the collective farm» (Hryshenchuk, 1938 r.n.). In the end, «where could you go if not to the collective farm. Those who do not go to work, are forced and ordered. We lived in a collective farm only» (Shevtsova, 1940 r.n.), "we didn't know another life» (Shevchuk, 1937 r. n.).

Absolutely all of our respondents associate collective farms with negative memories, which are still filled with feelings of fear, doom to a miserable life without rights. «We were all in the collective farm. Where were we supposed to be, as there was nothing else anywhere?» (Soroka, 1940 r.n.); «there was a collective farm. Dad and mom worked in the 
INTERMARUM: history, policy, culture. - Issue 9.

collective farm. Then I grew up, and they gave the beetroots for me also», says Halyna Afanasieva (Afanasieva, 1933r.n); Olga Goncharuk also claims that «everyone worked in this collective farm» (Honcharuk, 1936 r.n.).

A separate plot of memories of the collective farm life are unaffordable taxes, which were imposed on all peasants. People were actually deprived of the right to choose. It was almost impossible to survive outside the collective farm in the village. Those who resisted joining the collective farm, faced either an unbearable tax burden or repressions. "A cow calves a calf - you have to give it to the collective farm for free, you kill a piglet - hand over the skin to the state, and if you keep a horse - then the taxes are so terrible that you are not happy with that horse. for a piglet we could be fined, so the mother took it to the house (not in the house, but in the corridor). This was the way the collective farms were, this is how the people suffered» (Hryshenchuk, 1938 r.n.).

No less painful are the memories of our respondents about the total poverty caused not only by the post-war devastation, but also by the contempt for collective farmers from the state. In particular, it is about the absence either of monatary salary for hard peasant work, nor any social benefits. Each woman emphasized the poverty of postwar life. Moreover, they noted that the reason for this situation was that their parents worked hard on the collective farm almost for free, for «trudoden'»" (working days), or, as they said than, for "stick». "They paid for working days, but working days were meager, because $75 \%$ of the working day is one working day for the whole day from morning till evening. Those who could, went to the collective farm, and those who could not, crawled and worked, because people swelled up, they had nothing to eat» (Soroka, 1940 r.n.); «You work for whole day, and you earn a tick, one tick, one working day, they put a tick. They didn't pay money for a month for this tick, only at the end of the year gave out 10 or 20 coins for this tick. The much they had. And maybe you could get 200 grams of some grain, because you have worked the whole year, so you can bring this grain home on your shoulders» (Honcharuk, 1936 r.n.); «Labor days were recorded as a day, so the working day, and the salary

\footnotetext{
"Trudoden' - is a measure of assessment and a form of accounting for the quantity and quality of labor on collective farms in the period from 1930 to 1966.
} 
ІНТЕРМАРУМ: історія, політика, культура. - Вип. 9.

was given in grain. As for money, they gave it later in small amount, but there was no money at the beginning» (Afanasieva, 1933 r.n.). "And the working day, we work, we work, and we will be recorded... we have to work for three days for one working day. Yes, because there was a big working plan».

The main labor resource in the collective farms during the postwar decade were women and children. Respondents, whose childhood dates back to the 1940s, worked with their mothers in collective farms, cultivated beetroot crops, or helped to thresh the wheat, rye, or collect flax during the harvest. Moreover, some women recall that as teenagers they worked on a collective farm equally with adults, because they were also given working plans for cultivating beetroot plantations. For their work in the collective farm, they received working days. As if apologizing for their needy childhood, the peasants often emphasized that «we were not the only ones who lived like that, but all the people lived like that» (Honcharuk, 1936 r.n.).

According to estimates by Ukrainian scientists, «the monetary part of the budget of the family of a collective farmer in 1946 consisted of $2 \%$ of the money received for work in the collective farm by working days and additional payment for work, $8 \%$ - from pensions, $65 \%$ - from the money received from the delivery and selling of livestock, poultry, agricultural products and hunting» (Tereshchenko, 2016, p.116). The absence of a system of household and trade services in the village, unpaid collective farm work pushed people, mainly women, to look for ways to meet the household needs of their families. In order to survive in such conditions, the female peasants had to weave cloth on their own, sew clothes, and find an opportunity to earn money by selling products from their farms at the market. "Once my mother goes to the market (in a neighboring town). She will sell something there and buy soap, fat, matches. We sold butter, milk and bought everything we needed» (Afanasieva, 1933r.n.) Halyna Lavrivna tells her story of survival: «My mother was given a little sugar for her working day, then she carried it to the market and sold it, so that she could buy me a piece of fabric and sew a dress. I remember, when the war ended all sorts of silks were brought from Germany. And my mother really wanted me to be well dressed. Therefore, she leads me, buys, and Zhenia Nima sews. That was the way I walked» (Bilonih, 1939 r.n.); "we went to the market, carried what was harvested, or took some liter of milk, saved, or some egg, or some onion 
INTERMARUM: history, policy, culture. - Issue 9.

harvested on a land, so we took it in boxes, we had such. People walked to Zhytomyr by foot. What you sold, you could buy, maybe a half of loaf of bread, because after the war even a loaf of bread was not given in hands, only half of loaf» (Soroka, 1940 r.n.). Some of the women emphasized during the interview that the market trading had a certain danger. Traders who sold clothes, shoes or other household items at the market were called speculators, «they sold a lot of clothes and everything secretly, because the police fined and prosecuted. Shoes were sold there too» (Afanasieva, 1933 r.n.).

Another sore point of childhood memories of peasant women is the famine of 1946-1947. In their stories, they usually retell their own experience of going through these events - «I only remember that the soup was cooked with weed and everything else was done with it, too» (Afanasieva, 1933 r.n.); «I remember well. Potatoes, which remained from the Germans in the winter, were dug out of the ground in the spring, and it was rotten; it was washed, made the potato flour, and baked pancakes or dumplings. It was difficult, very difficult to live» (Vdovychenko, 1939 r.n.); «I remember very well. I was 6 years old, our cow was stolen, we were left without a cow and without milk and we have the youngest children, we were very poor. We wanted to eat the most. We had a clamp with the frozen potatoes under the forest and we all went there like crows, collected that frozen potatoes and baked donuts of it and so we survived» (Soroka, 1940 r.n.). The events of 1946-1947 were most clearly etched in the memories of our respondents with a feeling of constant hunger. Some of them tell about cases of cannibalism about which they heard from the stories of fellow villagers or rumors. It is significant that the peasants did not give political assessment of the famine in terms of the criminality of the communist government. Hunger for them is, first of all, a stigma at the level of family or village history.

A common component of the experience of survival of peasants in the famine of 1946-1947 were trips to the western regions of Ukraine in search of food. "Western» in the imagination of the inhabitants of Zhytomyr region looked like «a region where they lived better. They took things in there to exchange and brought grain back. They rubbed it with a bottle and boiled»(Mykhalchenko, 1939 r.n.). During the interviews, many female peasants said that their parents, leaving their children, «went to the West by train for bread» (Turbal, 1937 r.n). «My mother went to the West», Vira Hryhorivna recalls, - bring there something, 
ІНТЕРМАРУМ: історія, політика, культура. - Вип. 9.

exchange, bring it by foot, since there were noone, so bring something by foot. She went with my brother, could bring a pound; we grind it with millstones, tear it, cook the soup, put it into it; we had also a little of potatoes, but still we survived» (Parii, 1930 r.n). «My father goes to the West, is hired there to work either at the mill, or wherever», recalls $\mathrm{H}$. Bilonig. Thus he threshes, thus he digs a well». (Bilonig, 1939 r.n.). Such trips to neighboring western regions were accompanied by conditions of constant danger. Firstly, the authorities tried to prevent the spread of such migration. The appearance of hundreds of hungry and ragged «colhosnyky» («collective farmer») (as Galicians called peasants from the central regions of Ukraine) in the region where the Ukrainian insurgent movement spread, served as a clear illustration of the results of a «bright collective farm future». On the other hand, the authorities feared the spread of nationalist ideas in the territory of Greater Ukraine, the potential carriers of which could be those who went to the western Ukrainian region, seeking salvation from starvation there. Additionally, people returning home with food could be robbed on the way or even killed. However, according to our respondents, despite the danger, such trips were one way to survive the famine of 1946-1947.

The Conclusions. Summarizing the above, it should be noted that women's survival strategies in the post-war everyday life differed by extreme nature and the ability to adapt to circumstances. The de facto absence of male support in the village, due to the mobilization of men to the front during the final period of the war, forced women to take on some functions that were not traditionally part of their responsibilities tillage (such as plowing, mowing, etc.). construction of houses, dugouts, etc. In addition, they had the responsibility of organizing the family's everyday life: providing children with food, clothing, shoes, basic necessities and their upbringing. The state policy of the Stalinist regime was aimed at strengthening the foundations of communist power and creating appropriate socio-economic conditions for the life of the peasantry was not included in the list of its priorities.

The nature of rural everyday life of the first postwar decade was determined by the peculiarities of the functioning of the collective farm system. During this period, the epicenter of rural life was not so much the private family as the collective farm as an important economic and social institution. Our women's memories are full of stories about the hard and miserable everyday life of a Ukrainian collective farmer, a constant 
INTERMARUM: history, policy, culture. - Issue 9.

feeling of hunger and fear of punishment for not working days, «theft» of collective farm property, etc. The famine, hard work of the collective farm and the poverty of post-war everyday life still remain a painful stigma in the social memory of rural women.

Gratitude. I would like to thank the members of the editorial board of the journal and the reviewers for their constructive remarks, wishes and consultations provided during the preparation of the article for publication.

Funding. The author received no financial support for the research, authorship, and/or publication of this article.

\section{References}

Asheshkevych, Ya. (2017). Teoretyko-metodolohichni zasady doslidzhennia istorii povsiakdennosti. Naukovyi visnyk Uzhhorodskoho universytetu. Seriia «Istoriia». Vypusk 2 (37). 139-143.

Baklazhko, O. (2013). Bazarna torhivlia v povsiakdennykhstratehiiakh meshkantsiv Cherihova v1943-1945 rr.. Humanitarnyi zhurnal. № 3. 133-136. URL: http://nbuv.gov.ua/UJRN/gumj_2013_3_15 (Accessed 29.07.2021)

Derzhavnyi arkhiv Zhytomyrskoyi oblasti [SAZhR - State Archive of Zhytomyr Region].

Isaikina, O. Pobut miskoho naselennia Ukrainy $\mathrm{v}$ povoiennyi period. URL: http://history.org.ua/LiberUA/978-966-2464-02-3/63.pdf. (Accessed 29.07.2021)

Kovpak, L. (2015). Sotsialno-pobutovi umovy zhyttia naselennia Ukrainy u druhii polovyni XX st. (1945-2000 rr.). K.: Instytut istorii Ukrainy NANU. $250 \mathrm{~s}$.

Michuda, V. (2017). Moralno-psykholohichnyi stan ta povedinka silskoho naselennia Ukrainy v roky holodu 1946-1947 rr. III Dunaiski naukovi chytannia: Holod 1946-1947 rr.: istorychni, filosofsko-psykholohichni ta pedahohichni aspekty: materialy mizhnarodnoi naukovo-praktychnoi konferentsii (18-19 travnia 2017r.). Izmail $326 \mathrm{~s}$.

Pushkareva, N., Liubychankovskyi, S. (2014). Ponymanie istorii povsednevnosti v sovremennom istoricheskom issledovanii: ot shkoly Annalov k rossiyiskoi filosofskoi shkole. Vestnik Leningradskogo hosydarstvennogo universiteta im. A. S. Pushkina. 7-21.

Savytska, O. (2015). Spekuliatsiia yak povsiakdenne yavyshche v zhytti meshkantsiv Chernihova u pisliavoienne desiatylittia (1943-1953 rr.). Siverianskyi litopys. № 6. 154-159.

Starodubets, G. (2019). Znakovo-symvolichni markery «prostoru pamiati» radianskoi liudyny povoiennoho pokolinnia. Materialy III-VI 
IНТЕРМАРУМ: історія, політика, культура. - Вип. 9. ISSN 2518-7694 (Print) ISSN 2518-7708 (Online)

Vseukrainskykh naukovo-praktychnykh konferentsii «Polityka pamiati v teoretychnomu ta praktychnomu vymirakh» (Rivne, 2016-2019 rr.). Rivne. 211215.

Starodubets, G., Sushyk, I. (2021). Content and directions of women organizations activities in Volyn (the second half of the 1940s - beginning of the 1950s). Skhidnoievropeiskyi Istorychnyi Visnyk-East European Historical Bulletin. № 18. 176-186.

Tsentralnyyi derzhavnyyi arkhiv hromadskykh obyednan Ukrayiny [CSAPOU - Central State Archives of Public Organizations of Ukraine].

Tereshchenko, T. (2016). Riven zhyttia ukrainskoho selianstva v 1943 1950 rr. (na materialakh tsentralnykh oblastei Ukrainy). Naukovi zapysky Natsionalnoho universytetu «Ostrozka akademiia». Seriia : Istorychni nauky. Vyp. 25. 114-120.

Tsentralnyi derzhavnyi arkhiv hromadskykh orhanizatsii Ukrainy, f.1, op.70, spr.197. Derzhavnyi arkhiv Zhytomyrskoi obl., f. p-76, op. 2, spr. 227

Yankovska, O. (2010). Povsiakdenne zhyttia hromadian URSR yak vtilennia polityky derzhavy (1945-1953 rr.). Istoriia povsiakdennosti: teoriia ta praktyka»: materialy Vseukr. nauk. konf., Pereiaslav-Khmelnytskyi, 14-15 trav. 2010 r. / [Uporiad.:Lukashevych O.M., Nahaiko T.Iu.]. PereiaslavKhmelnytskyi. $246 \mathrm{~s}$

Zapysano 14 lystopada 2019 r. u s. Levkiv Zhytomyrskoho raionu vid Pylypchuk Liubovi Dmytrivny, 1935 r.n.

Zapysano 27zhovtnia 2018 r. v s. Barashivka Zhytomyrskoho raionu vid Pantus Tetiany Ivanivny, 1925 r.n.

Zapysano 30 hrudnia 2017 r. u s. Sadky Zhytomyrskoho raionu vid Hryshenchuk Halyny Yuriivny, 1938 r.n.

Zapysano 11 kvitnia 2021 roku v s. Sokilcha Popilnianskoho raionu Zhytomyrskoi oblasti vid Bilonih Halyny Lavrivny, 1939 r.n.

Zapysano 13 travnia 2021r. v s. Talky Zhytomyrskoho raionu vid Parii Viry Hryhorivny, 1930 r.n.

Zapysano 14 travnia 2021r. v seli Zozulyntsi Khmilnytskyi raionu Vinnytskoi oblasti vid Soroky Marii Serhiivny, 1940 r.n..

Zapysano 15 travnia 2021 r. u m. Radomyshl Zhytomyrskoi oblasti vid Shevtsovoi Nadii Semenivny, 1940 r.n.

Zapysano 18 travnia 2021 r. v s. Halchyn, Andrushivskoho raionu, Zhytomyrskoi oblasti vid Afanasievoi Halyny Andriivny, 1933r.n.

Zapysano 19 travnia 2021 r. s. Studenytsia Korostyshivskoho raionu Zhytomyrskoi oblasti vid Honcharuk Olhy Savetivny, 1936 r.n.

Zapysano 19 travnia 2021 r. v s. Kalynivka, Olevskoho raionu, Zhytomyrskoi oblasti vid Vdovychenko Liubovi Petrivny, 1939 r.n.

Zapysano 25 hrudnia 2017 r. u s. Karvynivka Romanivskoho raionu Zhytomyrskoi oblasti vid Halitskoi Halyny Stanislavivny, 1936 r.n. 
INTERMARUM: history, policy, culture. - Issue 9.

Zapysano 25 hrudnia 2017 r. u s. Pavlenkivka, Zhytomyrskoho raionu vid Shevchuk Nadii Petrivny, 1937 r. n.

Zapysano 27 lystopada 2020 r. v s. Andriiashivka, Berdychivskoho raionu, Zhytomyrskoi oblasti vid Lompas Oleny Yosypivny, 1939 r. n.

Zapysano 7hrudnia 2019 r. u s. Levkiv, Zhytomyrskoho raionu vid Mykhalchenko Olhy Volodymyrivny, 1939 r. n.

Zapysano 8 lystopada 2020r. u s. Sloboda Sholomkivska Ovrutskoho raionu Zhytomyrskoi oblasti vid Turbal Hanny Oleksiivny, 1937 r.n.

Zapysano u 25 hrudnia 2017 v s. Yosypivka Starokonstiantynivskoho raionu Khmelnytskoi oblasti vid Vasyliuk Marii Demianivny,1931 r.n.

\section{Стародубець Галина. АНТРОПОЛОГІЯ ПАМ'ЯТІ СІЛЬСЬКОГО ЖІНОЦТВА ЖИТОМИРЩИНИ ПРО ПОВОСННЕ ПОВСЯКДЕННЯ Анотація}

Мета роботи. У статті висвітлюються особливості повсякдення украӥнського села в період пізнього сталінізму крізь призму жіночого досвіду виживання в перше повоєнне десятиліття. В основу дослідження покладено спогади селянок Житомирщини, чиє дитинство проходило в 1940-ві роки. Методологічною основою дослідження $\epsilon$ історикоантропологічний підхід, одним із проявів якого є історія повсякденності. Наукова новизна. Дослідження сільського повсякдення сільських мешканців Житомирщини з позииій гендерного підходу здійснюються вперше. Акиентується увага на стратегіях виживання селянок у повоєнний період. Аналізуються такі складові сільського повсякдення як: робота в колгоспі, способи забезпечення матеріально-побутових потреб родини, поведінка селян в умовах голоду 1946-1947 років. Висновки. Жіночі стратегії виживання в умовах повоєнного повсякдення вирізнялися екстремальністю та вмінням пристосуватися до обставин. В ией період епіщентром сільського буття виступала не стільки приватна родина, скільки колгосп як важливий економічний та соиіальний інститут. Голод, важка колгоспна праця та злиденність повоєнного повсякдення досі залишається у суспільній пам'яті сільського жіноитва болючою стигмою.

Ключові слова. Селянки, повсякдення, голод, жінки, колгосn, радянська влада, Житомирщина.

\section{Starodubeć Hałyna. ANTROPOLOGIA PAMIECCI KOBIET WIEJSKICH ŻYTOMIERZA O POWOJENNEJ CODZIENNOŚCI}

\section{Streszczenie}

Cel pracy. Artykuł ukazuje specyfikę życia codziennego na ukraińskiej wsi $w$ okresie późnego stalinizmu przez pryzmat kobiecego doświadczenia przetrwania $w$ pierwszej dekadzie powojennej. Badanie opiera się na wspomnieniach chtopek z Żytomierza, których dzieciństwo miało miejsce $w$ 
ІНТЕРМАРУМ: історія, політика, культура. - Вип. 9. ISSN 2518-7694 (Print) ISSN 2518-7708 (Online)

latach 40. XX wieku. Podstawa metodologiczna opracowania jest podejście historyczno-antropologiczne, którego jednym z przejawów jest historia życia codziennego. Nowość naukowa. Po raz pierwszy prowadzone sa badania wiejskiego życia codziennego mieszkańców wsi obwodu żytomierskiego z punktu widzenia ptci. Nacisk ktadziony jest na strategie przetrwania chtopskich kobiet $w$ okresie powojennym. Analizowane sq takie elementy wiejskiego życia codziennego, jak: praca $w$ kotchozie, sposoby zaspokojenia potrzeb materialnych $i$ domowych rodziny, zachowania chłopów w okresie głodu 1946-1947. Wnioski. Strategie przetrwania kobiet $w$ powojennej codzienności charakteryzowaty się skrajnościa i umiejętnościa dostosowania się do okoliczności. W tym okresie epicentrum życia na wsi stanowita nie tyle prywatna rodzina, ile kotchoz, jako ważna instytucja gospodarcza i spoleczna. Głód, ciężka praca kotchozów i bieda powojennej codzienności wciąz pozostaja bolesnym piętnem $w$ pamięci społecznej kobiet wiejskich.

Słowa kluczowe. Chłopi, życie codzienne, głód, kobiety, kołchoz, władza radziecka, obwód żytomierski.

Статтю надіслано до редколегії 25.08.2021 р. Статтю рекомендовано до друку 25.10.2021 p. 